\title{
The Degradation of Corrosion Resistance for Al 5083 Alloy after Thermal and Superplastic Forming Processes
}

\author{
J.C. Chang and T.H. Chuang
}

\author{
(Submitted 2 February 1998; in revised form 23 February 2000)
}

\begin{abstract}
Corrosion behavior, particularly the intergranular corrosion susceptibility of a superplastic Al 5083 alloy (denoted as Al 5083S) and a non-superplastic Al 5083 alloy (denoted as Al 5083N) with various thermal processes and a superplastic forming process, has been systematically evaluated. The nitric acid mass loss test (NAMLT) according to ASTM G 67 indicated that the weight loss of Al 5083S was larger than that of Al 5083N, which was due to the finer grain size in the former alloy. It also showed that superplastically formed specimens of $\mathrm{Al} 5083 \mathrm{~S}$ and the specimens of $\mathrm{Al} 5083 \mathrm{~S}$ and $\mathrm{Al} 5083 \mathrm{~N}$ treated with the same thermal process as the superplastically formed specimens suffered from severe intergranular corrosion. The serious intergranular corrosion of these specimens was attributed to the formation of continuous $\beta\left(\mathrm{Mg}_{2} \mathbf{A l}_{3}\right)$ precipitates at grain boundaries, i.e., the sensitization effect. Such a detrimental effect can be eliminated by a postforming annealing treatment at $345{ }^{\circ} \mathrm{C}$ for $1 \mathrm{~h}$. Furthermore, electrochemical measurements in a 3.5 wt. \% $\mathrm{NaCl}$ solution also revealed that the sensitized specimens possessed more active corrosion potential $\left(E_{\text {corr }}\right)$, breakdown potential $\left(E_{b}\right)$, and protection potential $\left(E_{p p}\right)$, as well as higher corrosion current density $\left(i_{\text {corr }}\right)$ and passive current density $\left(i_{p}\right)$, than those of the as-received specimens. Experimental results also showed that the corrosion resistance of the superplastically formed specimen was the worst among all specimens, which was attributed to the formation of cavities during the superplastic forming in addition to the sensitization effect caused by the thermal processing. The influences of both detrimental effects on the corrosion resistance of the Al 5083 specimens were also discussed.
\end{abstract}

Keywords Al 5083 alloy, intergranular corrosion, superplastic forming, thermal processing, sensitization, cavitation

\section{Introduction}

Al 5083 alloy has been widely used in structural materials that require corrosion resistance and moderate to high strength. Grain refinement of this alloy can be obtained by thermomechanical treatment, which improves its mechanical properties and results in superplasticity. ${ }^{[1]} \mathrm{A}$ superplastic forming technology has been developed, which becomes important in industry for manufacturing complex workpieces and replaces conventional stamping processes, especially for those materials with lower formability. ${ }^{[2]}$ The superplastic Al 5083 alloy (denoted as Al 5083S) has been commercialized and the superplastically formed components have been used in automotive industry to reduce vehicle weight and improve fuel efficiency. ${ }^{[3]}$ It also has the potential to be used in mechanical and architectural structures. However, due to the increase of grain boundaries in the superplastic Al 5083S, the susceptibility of intergranular corrosion of this alloy should be noted. Moreover, the superplastic forming processes of the $\mathrm{Al} 5083 \mathrm{~S}$ are usually performed at 450 to $550{ }^{\circ} \mathrm{C} .{ }^{[4]}$ It has been reported that Al-Mg alloys containing more than 3 wt.\% Mg, including Al 5083, will be sensitized at elevated temperatures above $100^{\circ} \mathrm{C}$ or higher. ${ }^{[5,6,7]}$ This is the result of the continuous forming of the highly anodic $\beta$ phase $\left(\mathrm{Mg}_{2} \mathrm{Al}_{3}\right)$ at grain boundaries. ${ }^{[5]}$ During exposure to corrosive environments,

J. C. Chang, Chemical Systems Research Division, Chung Shan Institute of Science and Technology, Lung-Tan, 325, Taiwan, R.O.C. T. H. Chuang, Institute of Materials Science and Engineering, National Taiwan University, Taipei, 106 Taiwan, Republic of China. galvanic coupling occurs between these grain boundary precipitates and the grain interiors, which can lead to severe intergranular attack. The intergranular corrosion susceptibility depends on the corrosion solution and the extent of intergranular precipitates, which is also a function of $\mathrm{Mg}$ content, fabrication, and the thermal process. ${ }^{[6,7]}$ Furthermore, an undesirable phenomenon, the formation of cavities, occurs during the superplastic forming of some alloys, especially aluminum alloys. The caviation phenomenon not only deteriorates the mechanical properties of the workpiece but also increases its susceptibility to corrosion. ${ }^{[4,8-10]}$ In our previous studies, it was found that the superplastically formed Al 7475 and Inconel 718, (INCO Alloys International, Inc., Huntington, WV) workpieces clearly showed an increase in susceptibility to corrosion in $3.5 \% \mathrm{NaCl}$ solution. ${ }^{[11,12]}$ All factors aforementioned will increase the subsequent corrosion tendency of the superplastically formed $\mathrm{Al} 5083$ alloy, especially intergranular corrosion susceptibility.

Although the processing of superplastic forming for $\mathrm{Al} 5083 \mathrm{~S}$ has been studied by some researchers, ${ }^{[8-10,13-15]}$ evaluation of the corrosion behavior of this alloy is scarce, which is important from a practical point. Moreover, the effects of sensitization on corrosion behavior caused by thermal processing and the cavitation formed during the superplastic forming should be clarified. In the present work, the degradation of corrosion resistance of a superplastic $\mathrm{Al} 5083$ alloy ( $\mathrm{Al}$ 5083S), before and after thermal and superplastic forming processes, was systematically investigated by weight loss method, electrochemical technique, and scanning electron microscope (SEM) observation. For comparison, specimens of a non-superplastic Al 5083 alloy (denoted as Al $5083 \mathrm{~N}$ ) with the same thermal histories as those used in the superplastic forming of $\mathrm{Al} 5083 \mathrm{~S}$ were also studied. Through these experimental results, the influences of sensitization and cavitation 
on the corrosion behavior of these specimens, particularly intergranular corrosion susceptibility, were also discussed.

\section{Experimental}

Sheet materials of commercial superplastic Al 5083 alloy (Al 5083S) with a thickness of $2 \mathrm{~mm}$ were used in this study. The Al 5083S, designated as S1, was supplied by SKY Aluminum Co. Ltd. (Japan). Table 1 shows the chemical compositions of this alloy as analyzed by inductively coupled plasma-atomic emission spectroscopy (ICP-AES). On the other hand, a commercial, nonsuperplastic Al 5083 alloy ( $\mathrm{Al}$ 5083N) with 2-mm thickness was also used in this investigation. The $\mathrm{Al} 5083 \mathrm{~N}$, designed as N1, alloy was purchased from Alcoa Co. (Alcoa Center, PA). The chemical composition of $\mathrm{Al} 5083 \mathrm{~N}$ is also shown in Table 1. Test solutions were prepared using reagent grade chemicals and high purity deionized water (Milli-Q SP, Millipore S.A., France).

Some disk specimens with a diameter of $13 \mathrm{~cm}$ were cut from a sheet of Al 5083S alloy and superplastically formed in a cylindrical die by argon blowing with a pressure of $0.35 \mathrm{MPa}$ (50 psi) at $500{ }^{\circ} \mathrm{C}$ for $1 \mathrm{~h}$. Figure 1(a) shows a typical pan-shaped workpiece after superplastic forming. The central cross-sectional profile of such a workpiece was demonstrated in Fig. 1(b). It indicated that the thickness was not uniform, usually thinner at the corner. The specimens for weight loss tests and electrochemical measurements were cut from the central section of the pan bottom. In order to evaluate the effect of the superplastic forming process on intergranular corrosion susceptibility, specimens of both $\mathrm{Al}$ 5083S and $\mathrm{Al} 5083 \mathrm{~N}$, designated as S3 and N2, respectively, were also prepared by heating at $500{ }^{\circ} \mathrm{C}$ for $1 \mathrm{~h}$ to simulate the thermal process of superplastic forming.

Some specimens of S2, S3, and N2 were further annealed at $345^{\circ} \mathrm{C}$ for $1 \mathrm{~h}$, which were designated as S4, S5, and N3, respectively. The thermal and forming processes of all the specimens prior to corrosion tests are summarized in Table 2 . The detrimental effects caused by these treatments are also given in Table 2.

The susceptibility of intergranular corrosion was determined by the NAMLT test according to ASTM G67-93. The dimension of the specimens was $50 \times 6 \mathrm{~mm}$ with a thickness of $2 \mathrm{~mm}$. They were cut along the rolling direction and polished with emery paper to 320 grit. Then, the specimens were etched in a 5 pet sodium hydroxide $(\mathrm{NaOH})$ solution at $80^{\circ} \mathrm{C}$ for $60 \mathrm{~s}$, desmut in a concentrated nitric acid $\left(\mathrm{HNO}_{3}\right)$, and rinsed with deionized water. After drying in air, the specimens were weighed to an accuracy of near $0.1 \mathrm{mg}$. The NAMLT test was then conducted by immersing the specimens in a $70 \% \mathrm{HNO}_{3}$ solution at $30 \pm 1{ }^{\circ} \mathrm{C}$ for $24 \mathrm{~h}$. Then, they were washed in deionized water and acetone, dried in air, and weighed again.

Cyclic polarization measurements were conducted in an aerated $3.5 \mathrm{wt}$.\% sodium chloride $(\mathrm{NaCl})$ solution with a potentiostat (M273A, EG \& G PARC, TN). Before testing, the specimens

Table 1 Chemical compositions of Al 5083 alloys (wt.\%)

\begin{tabular}{lccccccccc}
\hline Alloy & Mg & Mn & $\mathbf{C r}$ & Si & Fe & $\mathbf{C u}$ & $\mathbf{T i}$ & $\mathbf{Z n}$ & $\mathbf{A l}$ \\
\hline Al 5083S & 4.46 & 0.67 & 0.10 & 0.09 & 0.05 & 0.02 & 0.01 & 0.01 & bal \\
Al 5083N & 4.36 & 0.78 & 0.08 & 0.06 & 0.08 & 0.02 & 0.01 & 0.01 & bal \\
\hline
\end{tabular}

were polished with emery paper to 600 grit, then degreased with acetone in an ultrasonic cleaning bath and rinsed in deionized water. The exposed surface area of the working electrode was 30 $\mathrm{mm}^{2}$ of the longitude-transverse (L-T) plane. The specimens were immersed in the test solution for 30 minutes to approach a steady-state condition. Cyclic polarization curves were obtained by the potentiodynamic technique, with a scanning rate of 1 $\mathrm{mV} / \mathrm{s}$. The potentials were scanned from $-250 \mathrm{mV}$ against the corrosion potential $\left(E_{\text {corr }}\right)$ to the threshold current density of 50 $\mathrm{mA} / \mathrm{cm}^{2}$, then reversing the scan until the hysteresis loop was closed. All potentials were measured and quoted against a saturated calomel electrode (SCE).

To observe the general microstructure via optical microscope, the specimens were prepared by polishing and etching with Graf Sergeant reagent $\left(15.5 \mathrm{~mL} \mathrm{HNO}_{3}, 0.5 \mathrm{~mL}\right.$ hydrogen fluoride (HF), $3 \mathrm{~g}$ chromium acid $\left(\mathrm{CrO}_{3}\right)$, and $84 \mathrm{~mL}$ deionized water). ${ }^{[10]}$ To identify the $\beta$-phase precipitates, the specimens with various thermal processes were selectively etched with a $40 \%$ phosphoric acid $\left(\mathrm{H}_{3} \mathrm{PO}_{4}\right)$ solution then examined by SEM. The corrosion morphologies after the NAMLT test were also observed by SEM.
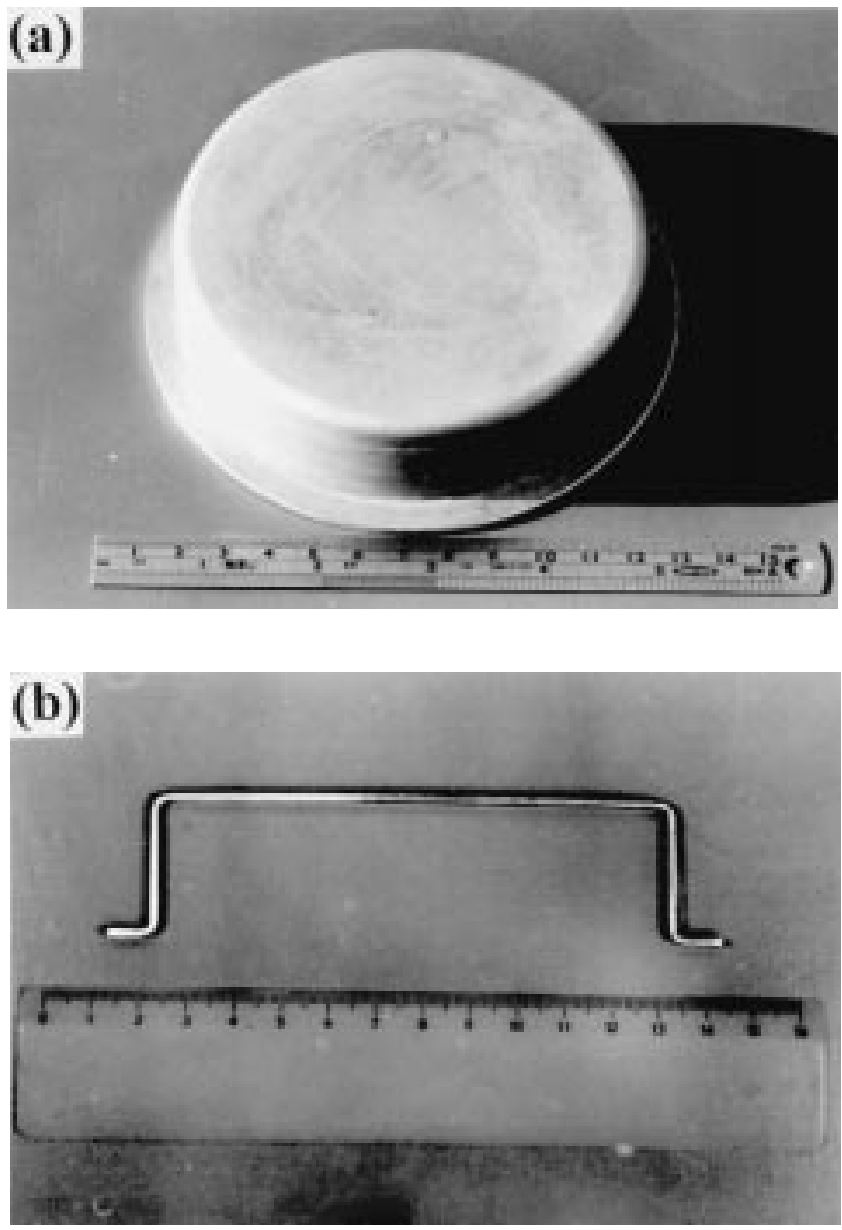

Fig. 1 (a) The typical pan-shaped workpiece after superplastic forming. (b) The central cross-sectional profile of the workpiece 
Table 2 Various heat treatments and the accompanying effects in superplastic and nonsuperplastic Al 5083 alloys

\begin{tabular}{|c|c|c|c|}
\hline Specimen & Material & $\begin{array}{l}\text { Temper } \\
\text { conditions }\end{array}$ & $\begin{array}{l}\text { Detrimental } \\
\text { effects }\end{array}$ \\
\hline $\mathrm{S} 1$ & Al 5083S & as-received & \\
\hline $\mathrm{S} 2^{(\mathrm{a})}$ & $\mathrm{Al} 5083 \mathrm{~S}$ & $\begin{array}{l}\text { superplastically } \\
\text { formed }\end{array}$ & $\begin{array}{l}\text { sensitization } \\
\text { and cavitation }\end{array}$ \\
\hline $\mathrm{S} 3^{(\mathrm{b})}$ & $\mathrm{Al} 5083 \mathrm{~S}$ & $\begin{array}{l}\text { heat treated } \\
\text { with the same } \\
\text { thermal process } \\
\text { as superplastic } \\
\text { forming } \\
\text { specimen (S2) }\end{array}$ & sensitization \\
\hline $\mathrm{S} 4^{(\mathrm{c})}$ & $\mathrm{Al} 5083 \mathrm{~S}$ & $\begin{array}{l}\text { postannealing } \\
\text { after superplastic } \\
\text { forming }\end{array}$ & cavitation \\
\hline $\mathrm{S} 5^{(\mathrm{c})}$ & Al 5083S & $\begin{array}{l}\text { postannealing } \\
\text { of the S3 } \\
\text { specimen }\end{array}$ & \\
\hline N1 & $\mathrm{Al} 5083 \mathrm{~N}$ & as-received & \\
\hline $\mathrm{N} 2^{(\mathrm{b})}$ & $\mathrm{Al} 5083 \mathrm{~N}$ & $\begin{array}{l}\text { heat treated } \\
\text { with the same } \\
\text { thermal process } \\
\text { as superplastic } \\
\text { forming }\end{array}$ & sensitization \\
\hline $\mathrm{N} 3^{(\mathrm{c})}$ & Al 5083N & $\begin{array}{l}\text { postannealing of } \\
\text { the N2 specimen }\end{array}$ & \\
\hline \multicolumn{4}{|c|}{$\begin{array}{l}\text { (a) Superplastic forming by } 0.35 \mathrm{MPa} \text { ( } 50 \mathrm{psi} \text { ) argon pressure at } 500^{\circ} \mathrm{C} \text { for } \\
1 \mathrm{~h} \text {, then furnace cooled } \\
\text { (b) Heat treated at } 500^{\circ} \mathrm{C} \text { and } 0.35 \mathrm{MPa} \text { ( } 50 \mathrm{psi} \text { ) for } 1 \mathrm{~h} \text { without superplas- } \\
\text { tic forming, then furnace cooled } \\
\text { (c) Postannealing at } 345^{\circ} \mathrm{C} \text { for } 1 \mathrm{~h} \text {, then air cooled }\end{array}$} \\
\hline
\end{tabular}

\section{Results and Discussion}

\subsection{Susceptibility to Intergranular Corrosion}

The typical grain structure of the as-received $\mathrm{Al}$ 5083S (S1), Al 5083N (N1), and superplastically formed Al 5083S (S2) are shown in Fig. 2(a), (b), and (c), respectively. The grain sizes measured by the mean linear intercept method based on ASTM E112 are listed in Table 3. The measurement revealed that $\mathrm{Al} 5083 \mathrm{~S}$ possessed an approximately 50\% finer grain size than that of Al 5083N. Table 3 also shows that the grain growth of these alloys under various thermal processes in this study was negligible, except for that of the superplastically formed specimen.

The grain size of the superplastically formed specimen (S2) increased by about $65 \%$, compared to that of the as-received specimen (S1). The grain growth rate was similar to that obtained in a tension test reported by Verma et al. ${ }^{[8]}$ However, the grain size of the specimens treated with the same thermal process as superplastic forming (S3) apparently was not changed, as shown in Table 3. After superplastic forming, cavities were also found in the specimens, as shown in Fig. 3(a). In addition to the large cavities formed in the intersection of triple grain boundaries, many small cavities were also found at the grain boundaries, as shown in the magnified micrograph of Fig. 3(b).

Table 4 demonstrated the results of the NAMLT test of those $\mathrm{Al} 5083$ specimens. The weight loss was 5.6 and $3.2 \mathrm{mg} / \mathrm{cm}^{2}$ for
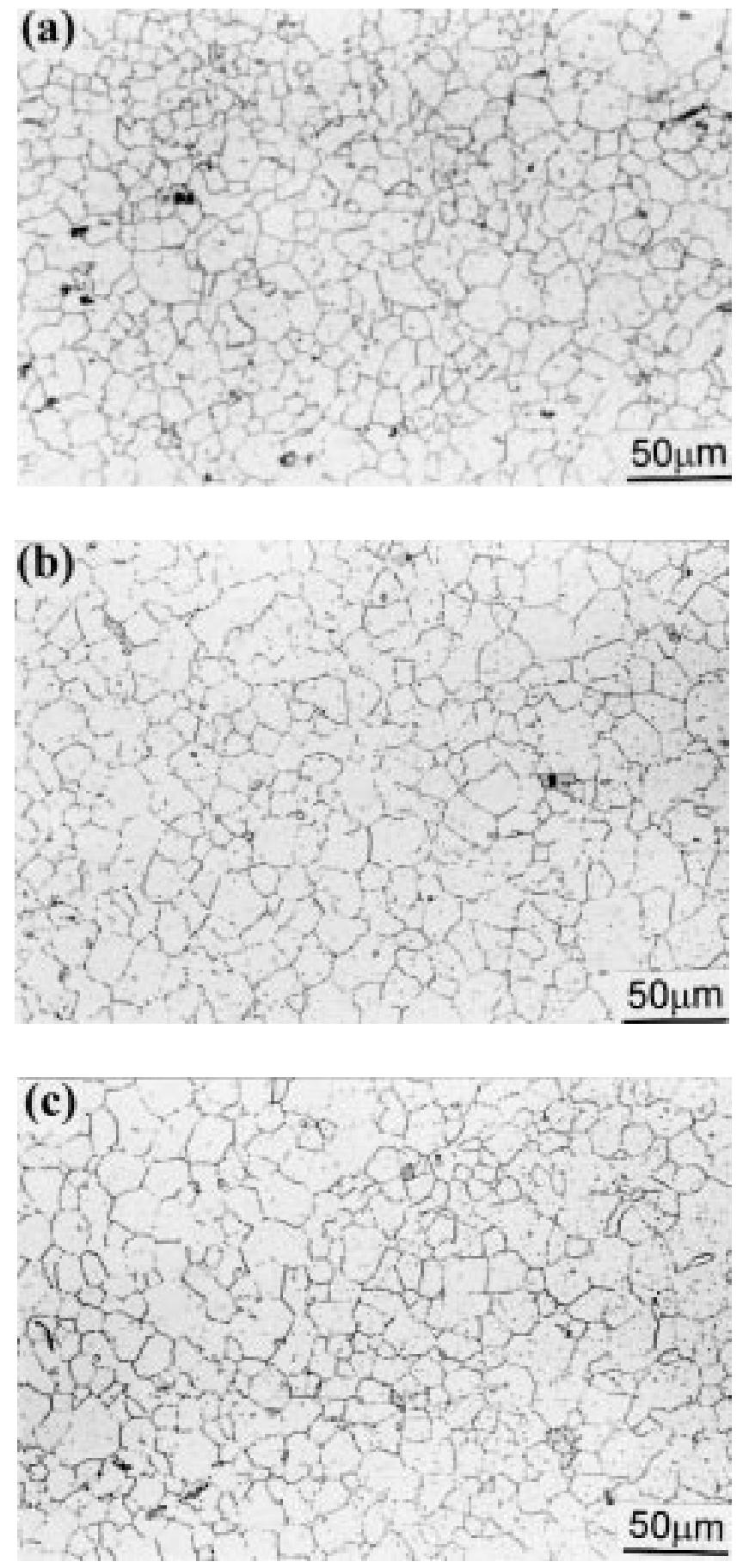

Fig. 2 The typical optical micrographs of the A1 5083 alloys: (a) S1, (b) N1, and (c) S2

the as-received specimens (S1 and N1), respectively. ASTM G 67 suggests the amount of weight loss should be less than $25 \mathrm{mg} / \mathrm{cm}^{2}$ for a good intergranular corrosion resistance property of the $5 \mathrm{xxx}$ series aluminum alloys, implying that both the $\mathrm{S} 1$ and N1 were low in susceptibility to intergranular corrosion. It can also be seen that the weight loss of the fine grain-sized S1 specimen was larger than that of the larger grain-sized N1 specimen. 
Table 3 Intercept grain sizes and the surface area of grain boundaries of the Al 5083 alloys

\begin{tabular}{lccc}
\hline Specimen & $\begin{array}{c}\text { Longitudinal } \\
\text { direction }(\mu \mathbf{m})\end{array}$ & $\begin{array}{l}\text { Long transverse } \\
\text { direction }(\mu \mathbf{m})\end{array}$ & $\begin{array}{l}\text { Surface area of grain } \\
\text { boundaries }\left(\mathbf{c m}^{2} / \mathbf{c m}^{3}\right)\end{array}$ \\
\hline S1 & $9.6 \pm 0.5$ & $7.5 \pm 0.4$ & $2.54 \times 10^{3}$ \\
S2 & $15.8 \pm 0.7$ & $9.2 \pm 0.5$ & $1.98 \times 10^{3}$ \\
S3 & $9.8 \pm 0.4$ & $7.3 \pm 0.3$ & $2.59 \times 10^{3}$ \\
S4 & $15.9 \pm 0.7$ & $9.1 \pm 0.5$ & $2.00 \times 10^{3}$ \\
S5 & $9.7 \pm 0.4$ & $7.4 \pm 0.3$ & $2.56 \times 10^{3}$ \\
N1 & $18.6 \pm 0.7$ & $15.2 \pm 0.7$ & $1.26 \times 10^{3}$ \\
N2 & $18.3 \pm 0.7$ & $15.4 \pm 0.6$ & $1.25 \times 10^{3}$ \\
N3 & $19.1 \pm 0.7$ & $16.0 \pm 0.6$ & $1.21 \times 10^{3}$ \\
\hline
\end{tabular}
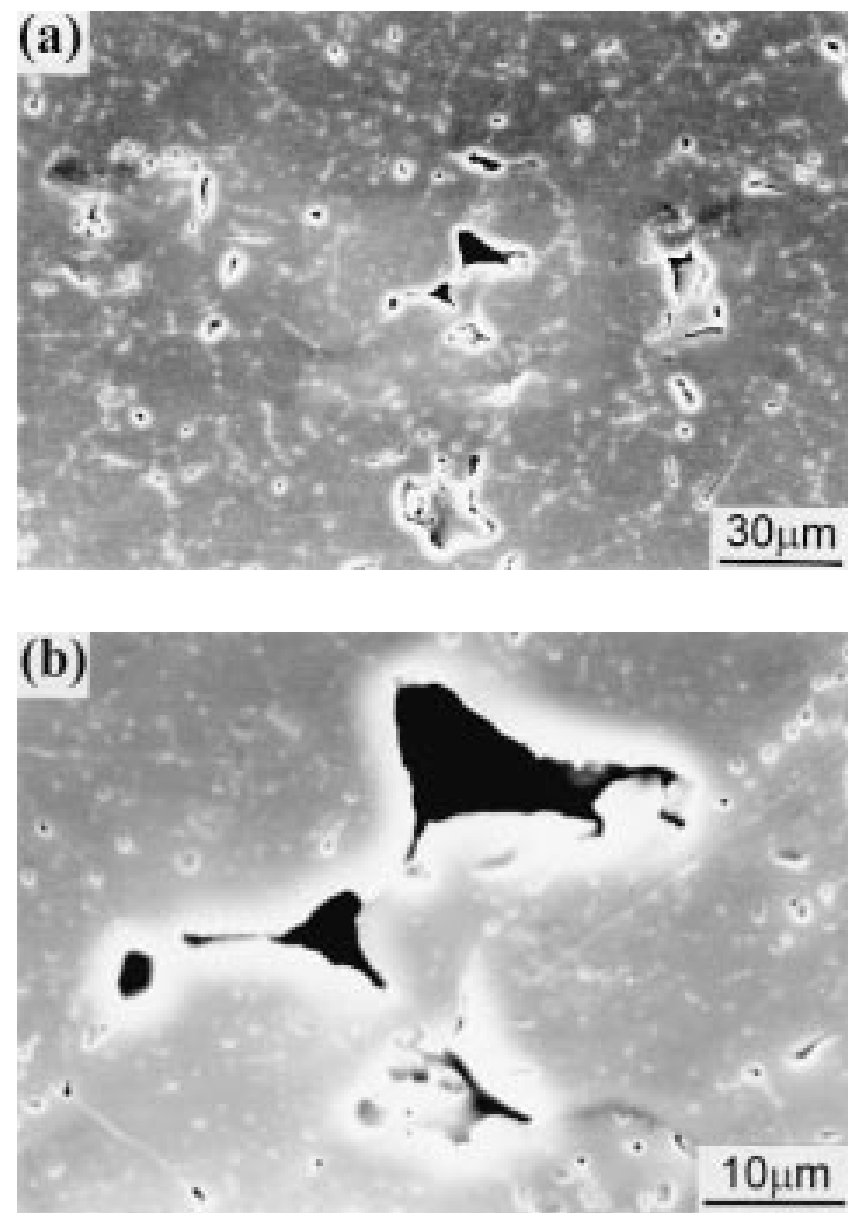

Fig. 3 (a) Cavitation formed in the superplastically formed specimen (b) The magnification of (a)

Results of the specific surface area of grain boundaries are also given in Table 3 . They were achieved by a quantitative metallurgy analysis and are defined by the ratio of grain boundary area to the volume of specimen. For a rolling material with partially oriented structures as used in this study, the specific surface area may be obtained by the following relation: ${ }^{[16,17,18]}$

$$
S_{v}=0.429\left(N_{L}\right)_{/ /}+1.571\left(N_{L}\right)_{\perp}
$$

Table 4 Results of NAMLT test for Al 5083 alloys

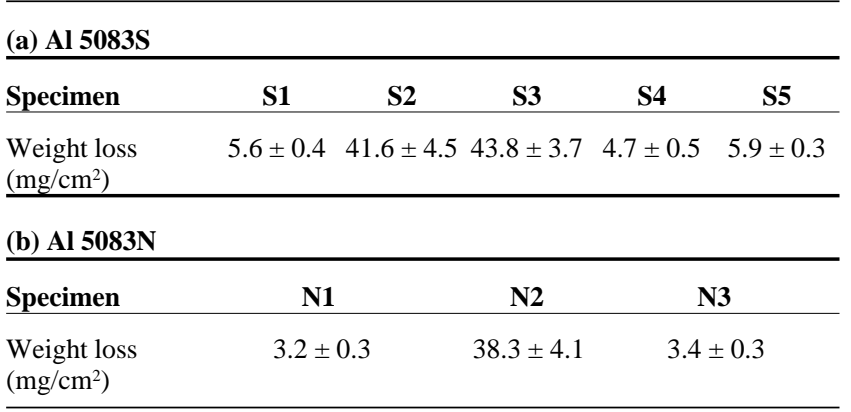

where $S_{v}=$ specific surface area, $\left(N_{L}\right)_{/ /}=$number of intersections with grain boundaries per unit length placed parallel to the rolling direction, and $\left(N_{L}\right)_{\perp}=$ number of intersections per unit length placed perpendicular to the rolling direction.

In Table 4, it was also clearly revealed that the weight losses of S2, S3, and N2 were much greater than those of the annealed specimens. In other words, specimens treated with the same thermal processes as superplastic forming (S3 and N2) resulted in a similar level of weight loss as that obtained after actual superplastic forming (S2). The severe susceptibility of intergranular corrosion for the aforementioned specimens was attributed to the sensitization effect of heat treatment during the superplastic forming process. Kaesche ${ }^{[19]}$ and $\mathrm{Craig}^{[20]}$ have reported that the Al 5083 alloy is susceptible to intergranular corrosion after exposure to moderately elevated temperature up to about $175^{\circ} \mathrm{C}$, which can be recovered by a postforming annealing treatment. In the present study, Table 4 also showed that the annealing treatment of the superplastically formed specimen and the specimens treated with the same thermal process as superplastic forming led to the recovery of intergranular corrosion susceptibility to a level approaching that of the original one.

Figure 4 presents the micrographs of the distributions of $\beta$-phase precipitates, which were selectively etched with a $40 \%$ $\mathrm{H}_{3} \mathrm{PO}_{4}$ solution. This etchant reveals only the $\beta$-phase precipitate and not the grain boundaries. ${ }^{[5]}$ From Fig. 4(a) and (b), the as-received specimens ( 1 1 and N1) possessed random distributions of small pits, while a continuous network of $\beta$-phase precipitates along grain boundaries appeared in the superplastically formed specimen (S2) (Fig. 4c). The specimens, S3 and N2, which were sensitized by the same thermal process as the superplastically formed specimens, showed morphologies similar to that of the $\mathrm{S} 2$. After further annealing of the superplastically formed specimen (S2), the microstructure returned to random distributions of $\beta$-phase precipitates, as shown in Fig. 4(d) for specimen S4. Such results also existed for the annealing of S3 and N2 specimens, which are shown in Fig. 4(e) and (f) for specimens S5 and N3, respectively. Both specimens showed the random distributions of $\beta$-phase precipitates as that of S4. The results are consistent with the opinions of Summerson and Sprowls ${ }^{[21]}$ and Dix et al. ${ }^{[2]}$ They reported that the intergranular corrosion susceptibility of the sensitized specimens can be eliminated by dissolution of the continuous precipitation layer along the grain boundaries, and the coarsened precipitates will form during the annealing treatment. 

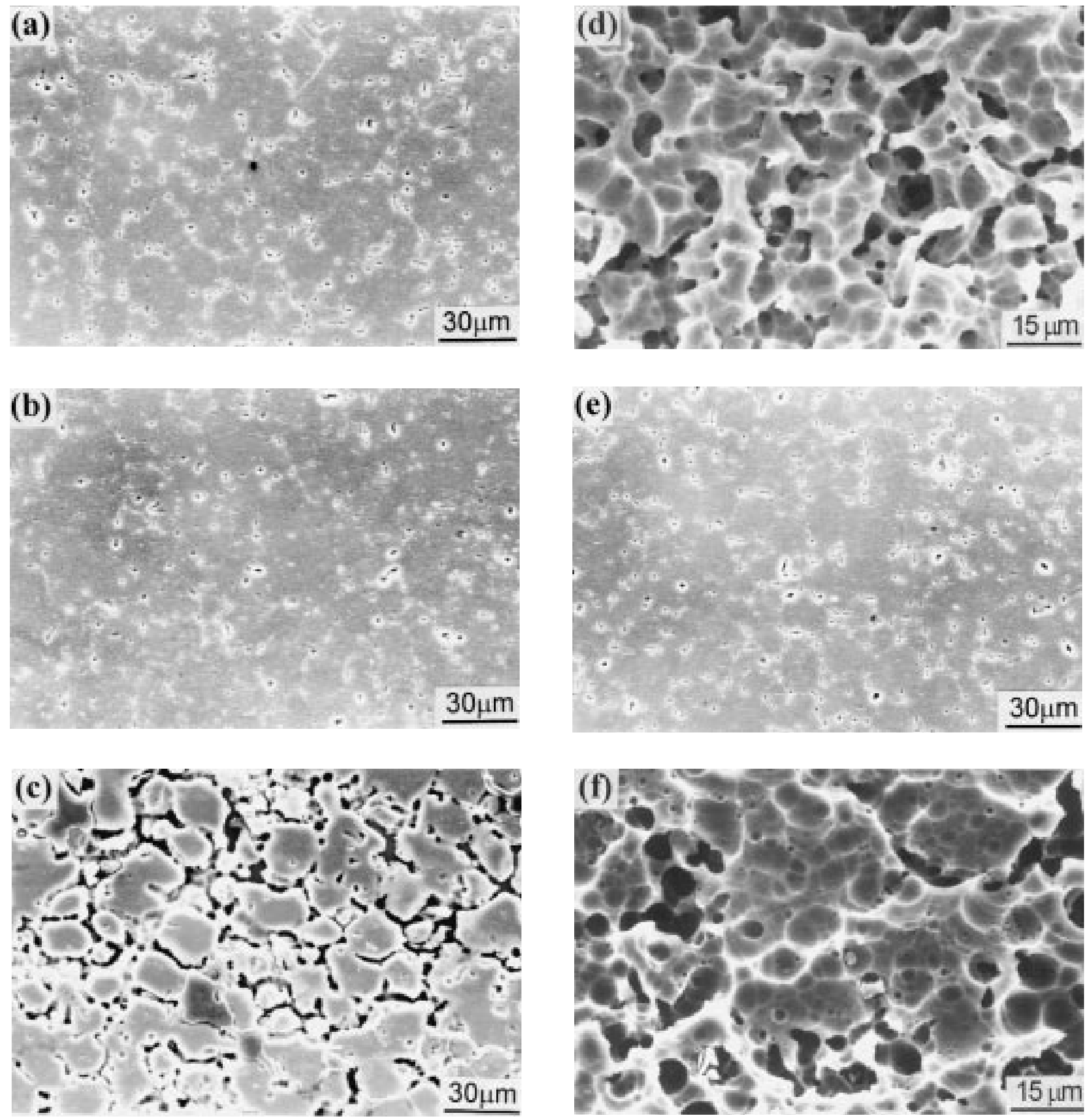

Fig. 4 SEM micrographs of $\beta$-phase precipitates selectively etched by phosphoric acid in Al 5083 alloys with various thermal processes: (a) S1, (b) $\mathrm{N} 1$, (c) S2, (d) S4, (e) S5, and (f) $\mathrm{N} 3$

Figure 5 shows the corrosion morphologies of the specimens after the NAMLT tests. Both S2 and S3 specimens were attacked mainly at the grain boundaries (Fig. 5b and c). The grains may drop off as a result of severe corrosion around the grain boundaries, ${ }^{[20]}$ leading to a large amount of weight loss, as shown in Table 4. A similar morphology was also found in Fig. 5(g) for the N2 specimens. However, the as-received spec- imens were only slightly attacked and corrosion occurred over the grain boundaries and inside the grains, as shown in Fig. 5(a), (d), (e), (f), and (h). From the results discussed above, it can clearly be seen that both the as superplastically formed specimen and the specimens treated with the same thermal process as superplastic forming were seriously susceptible to intergranular corrosion. 


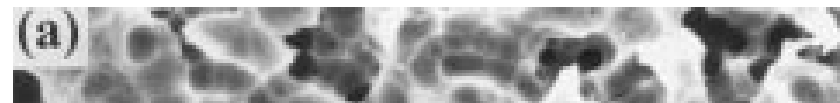

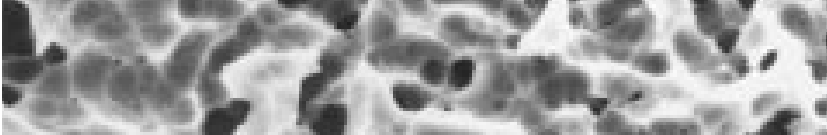

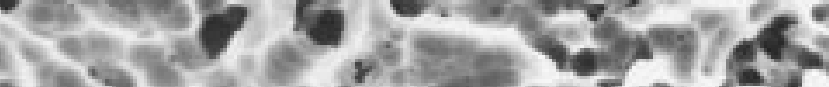

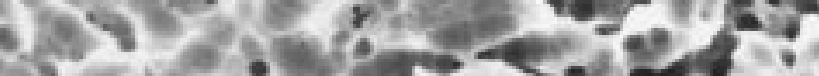

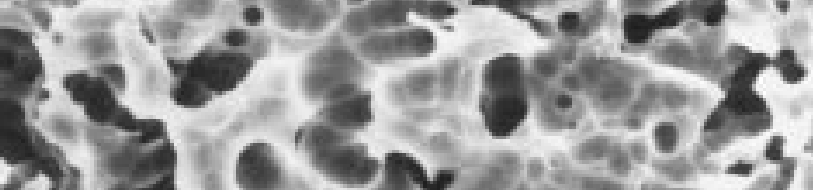

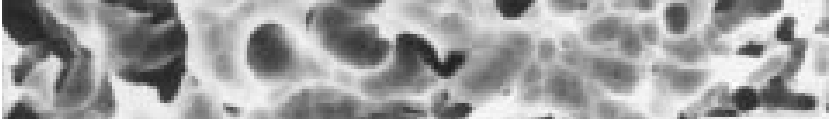

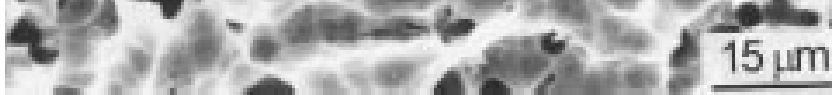
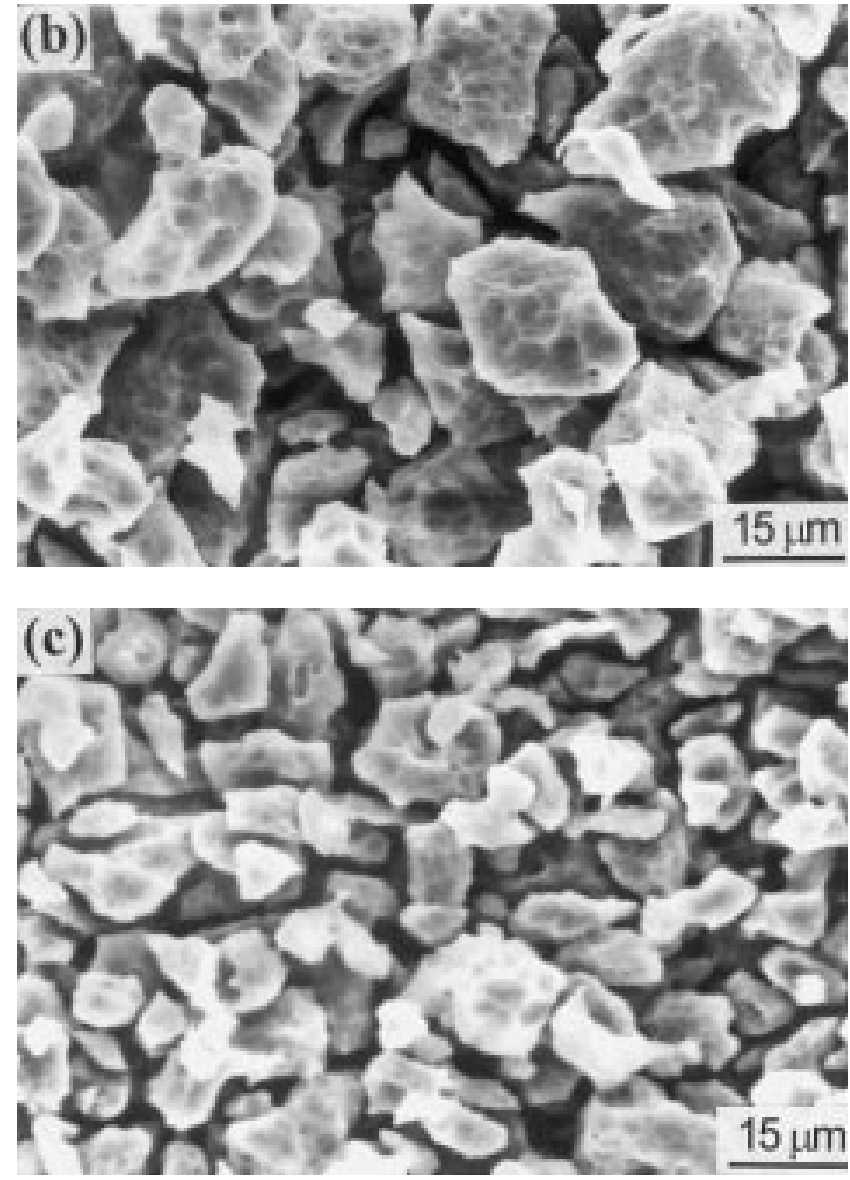

(d)

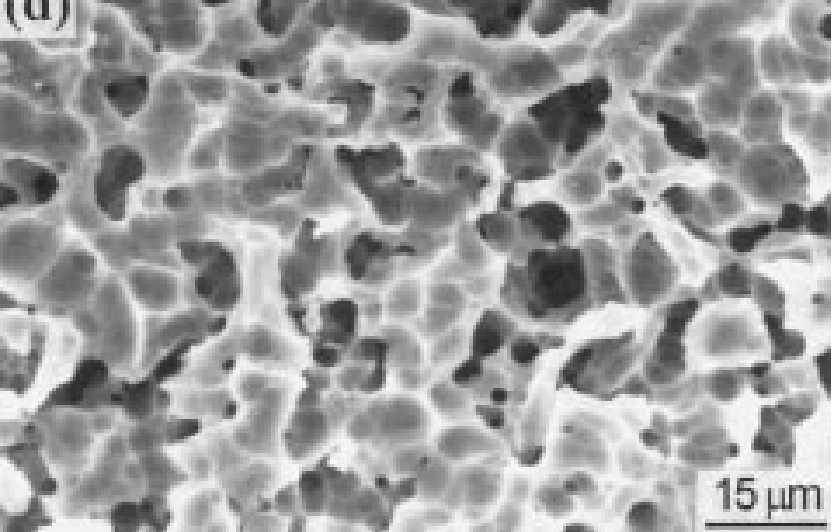

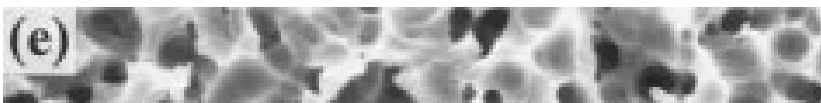

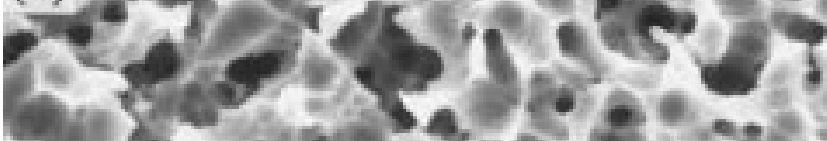

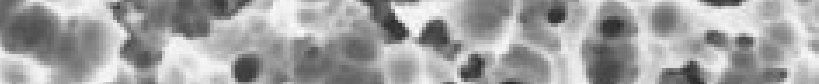

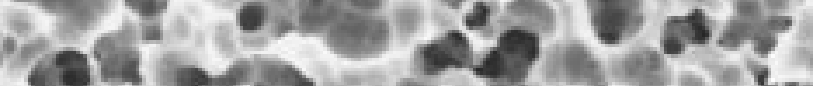

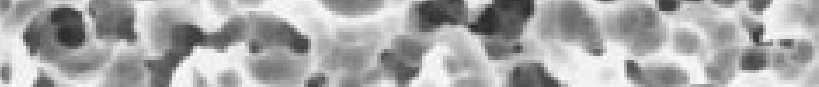
ines (a)

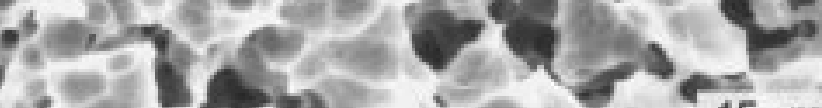
a $\Delta 0,0,15 \mu \mathrm{m}$
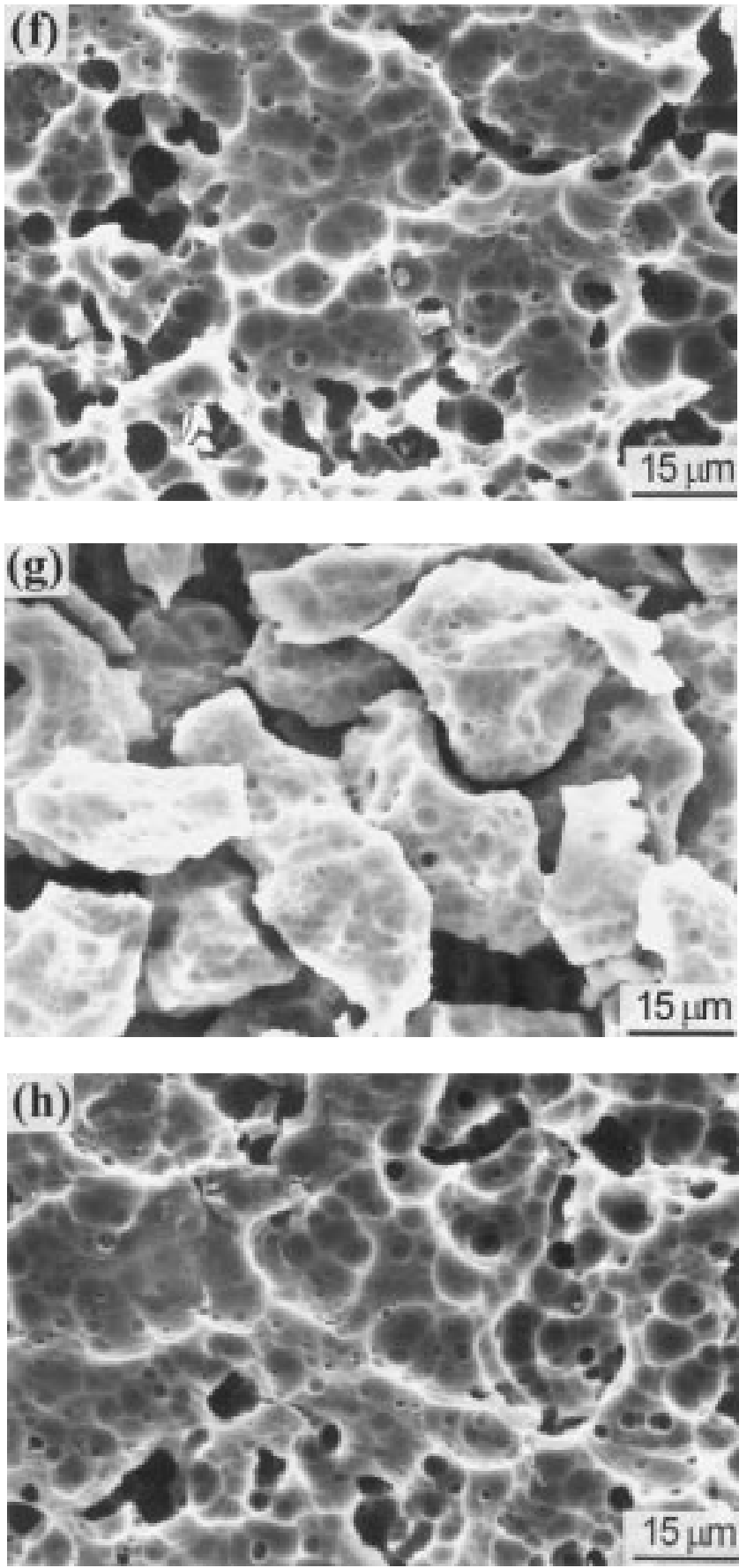

Fig. 5 SEM images of the Al 5083 alloys after NAMLT tests: (a) S1, (b) S2, (c) S3, (d) S4, (e) S5, (f) N1, (g) N2, and (h) N3 


\subsection{Electrochemical Behaviors}

Figure 6 shows the cyclic polarization curves of the Al 5083 specimens measured in a $3.5 \mathrm{wt} . \% \mathrm{NaCl}$ solution. The electrochemical parameters obtained from this figure are listed in Table 5. From Fig. 6(a), it is clear that the polarization curves of the as-received specimens (S1 and N1) were similar to each other. However, the electrochemical parameters of the superplastically formed specimen (S2), such as the corrosion potential $\left(E_{\text {corr }}\right)$, the breakdown potential $\left(E_{b}\right)$, and the protection potential $\left(E_{p p}\right)$, shifted to a more active direction compared to that of S1 and N1 specimens. The magnitude of the passive current density $\left(i_{p}\right)$ of the $\mathrm{S} 2$ specimen was also two to three times larger than that of the S1 and N1specimens, a result of the precipitation of the $\beta$ phase, which is highly anodic to the alloy matrix. ${ }^{[23]}$ Therefore, the difference in polarization behaviors of these specimens can be attributed to the larger tendency of the selective dissolution of the $\beta$ phase.

Table 5 Electrochemical parameters of Al 5083 alloys in 3.5 wt. \% NaCl solution

\begin{tabular}{lccccc}
\hline & $\begin{array}{c}\mathbf{E}_{\text {corr }} \\
(\mathbf{m V} \text { vs SCE) }\end{array}$ & $\begin{array}{c}\mathbf{E}_{\mathbf{b}} \\
(\mathbf{m V} \mathbf{v s ~ S C E})\end{array}$ & $\begin{array}{c}\mathbf{E}_{\mathbf{p p}} \\
(\mathbf{m V} \mathbf{~ v s ~ S C E})\end{array}$ & $\begin{array}{c}\mathbf{i}_{\text {corr }} \\
\left(\mu \mathbf{A} / \mathbf{c m}^{2}\right)\end{array}$ & $\begin{array}{c}\mathbf{i}_{\mathbf{p}} \\
\left(\mu \mathbf{A} / \mathbf{c m}^{2}\right)\end{array}$ \\
\hline S1 & -833 & -647 & -781 & 4.9 & 16.9 \\
S2 & -998 & -791 & -835 & 14.3 & 42.5 \\
S3 & -987 & -746 & -824 & 11.3 & 34.1 \\
S4 & -875 & -715 & -821 & 8.0 & 23.6 \\
S5 & -820 & -638 & -783 & 4.4 & 16.5 \\
N1 & -842 & -653 & -784 & 4.1 & 15.6 \\
N2 & -992 & -740 & -816 & 10.5 & 32.3 \\
N3 & -825 & -659 & -785 & 4.2 & 15.9 \\
\hline
\end{tabular}

$E_{\text {corr }}$ : corrosion potential; $E_{\mathrm{b}}$ : breakdown potential; $E_{\mathrm{pp}}$ : protection potential; $i_{\text {corr }}$ : corrosion current density; and $i_{\mathrm{p}}$ : passive current density

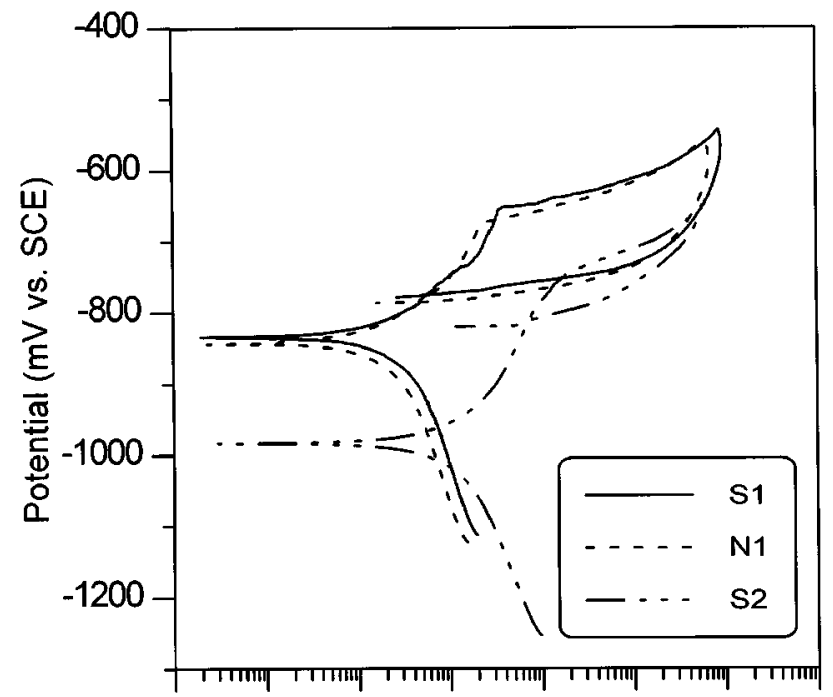

1E-8 1E-7 $\quad 1 \mathrm{E}-6 \quad 1 \mathrm{E}-5 \quad 1 \mathrm{E}-4$ 1E-3 $\quad 1 \mathrm{E}-2$ 1E-1

(a)

Current density $\left(\mathrm{A} / \mathrm{cm}^{2}\right)$
In order to evaluate the influences of sensitization and cavitation during the superplastic forming process on the electrochemical behavior of the various Al 5083 specimens, cyclic polarization was also performed for the specimens of S3 and N2, which were treated with the same thermal process as the superplastically formed specimens. The results shown in Fig. 6(b) indicate that the corrosion potentials $\left(E_{\text {corr }}\right)$ of S2, S3, and N2 specimens were similar to one another. However, the breakdown potential $\left(E_{b}\right)$ of $\mathrm{S} 2$ was about $50 \mathrm{mV}$ more active than that of the $\mathrm{S} 3$ and N2 specimens, and both the cathodic and anodic current densities of the S2 specimen were also higher than those of the $\mathrm{S} 3$ and N2 specimens. These results could be attributed to the

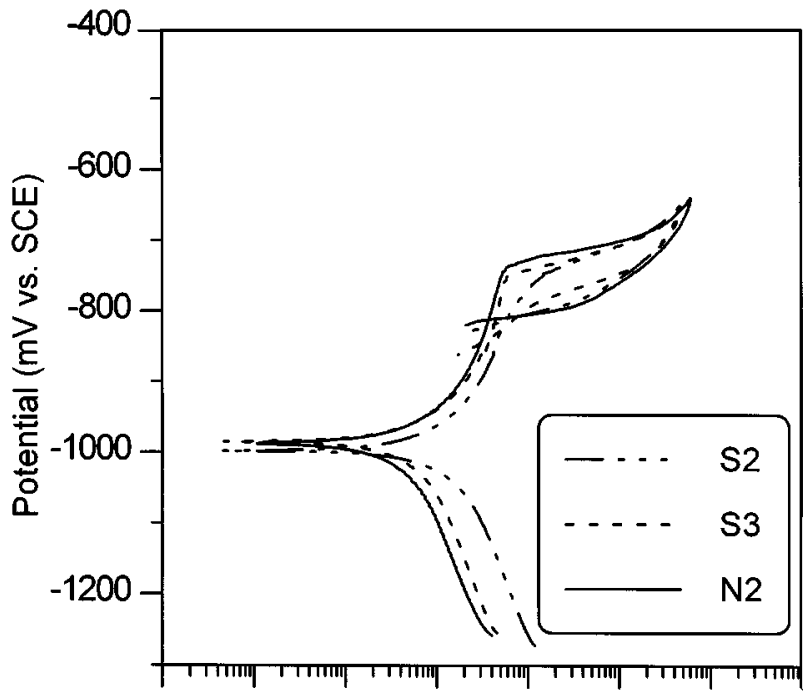

$1 \mathrm{E}-8 \quad 1 \mathrm{E}-7 \quad 1 \mathrm{E}-6 \quad 1 \mathrm{E}-5 \quad 1 \mathrm{E}-4 \quad 1 \mathrm{E}-3 \quad 1 \mathrm{E}-2 \quad 1 \mathrm{E}-1$ (b)

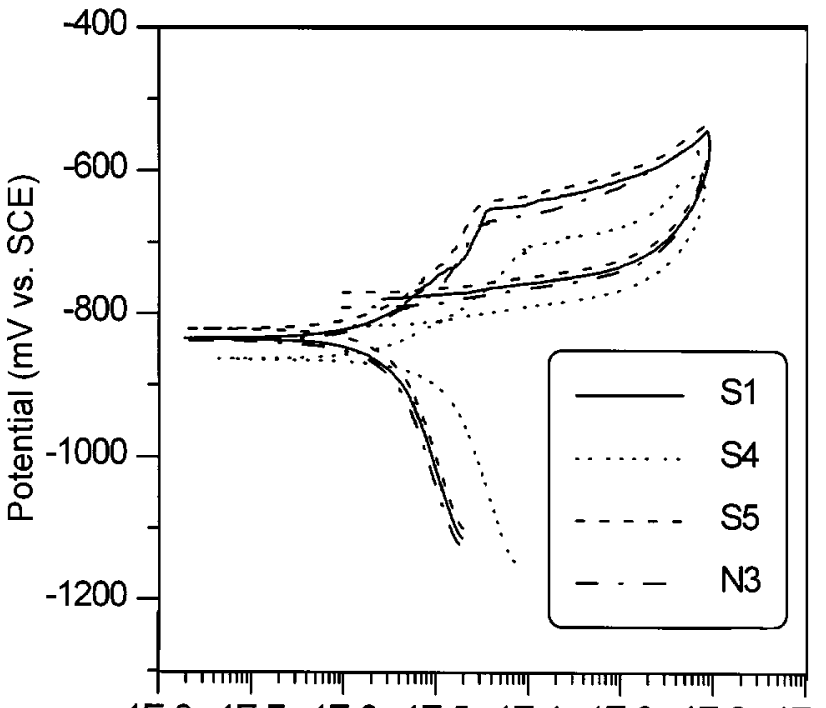

1E-8 1E-7 1E-6 1E-5 1E-4 1E-3 1E-2 1E-1

(c)

\section{Current density $\left(\mathrm{A} / \mathrm{cm}^{2}\right)$}

Fig. 6 Cyclic polarization curves of the $\mathrm{Al} 5083$ alloys in 3.5wt.\% NaCl solution: (a) S1, S2, N1; (b) S2, S3, N2; and (c) S1, S4, S5 N4 
cavitation formed in the S2 specimen during superplastic forming, since both S3 and N2 specimens were treated with the same thermal process as the $\mathrm{S} 2$ specimen with the exception of the superplastic forming of the $\mathrm{S} 2$ specimen. Because cavities are usually active sites for corrosion reaction, they caused pitting corrosion and led to the increase of corrosion current density $\left(i_{\text {corr }}\right)$ and passive current density $\left(i_{p}\right)$ values. ${ }^{[19,21]}$ Reducing the formation of cavities in this alloy using the back pressure technique suggested by Bampton et al. ${ }^{[24,25]}$ may eliminate the pitting corrosion tendency and increase the corrosion resistance of the superplastically formed workpiece.

Cyclic polarization curves of the postannealing specimens (S4, S5, and N3), i.e., annealed after superplastic forming or heat treated with the same thermal process as superplastic forming, were shown in Fig. 6(c). For comparison, the cyclic polarization curves of the as-received specimen (S1) were also given in this figure. It is worth noting that the $E_{\text {corr }}, E_{b}$, and $E_{p p}$ of S4 were apparently more active than those of the other specimens. In addition, both the cathodic and anodic current densities of the S4 specimen were also the highest among these specimens. The results could be attributed to the retention of cavitation in S4, which was formed during superplastic forming. The electrochemical behavior of S5 and N3 was similar to that of the S1 specimen.

From the values of $i_{\text {corr }}$ shown in Table 5, it was proposed that the ratio of the sensitization effect to cavitation effect for the intergranular corrosion susceptibility of a superplastically formed Al 5083 alloy could be expressed as

$\left[i_{\text {corr }(\mathrm{S} 3)}-i_{\text {corr(S1) }}\right]:\left[i_{\text {corr(S4) }}-i_{\text {corr(S1) }}\right]=6.4: 3.1$

This implies that the sensitization effect was approximately twice as dominant as the cavitation effect.

\section{Conclusions}

The susceptibility of $\mathrm{Al} 5083 \mathrm{~S}$ to intergranular corrosion was more severe than that of $\mathrm{Al} 5083 \mathrm{~N}$. The higher weight loss of the Al 5083S specimen as measured by the NAMLT test was caused by its finer grain size. Results of the NAMLT tests also showed that the superplastically formed specimen (S2) and the specimens S2 and N3 treated with the same thermal process as superplastic forming also suffered from intergranular corrosion, primarily attributed to the effect of sensitization. The weight losses of the S2, S3, and N2 specimens were similar. The intergranular corrosion of the $\mathrm{S} 2, \mathrm{~S} 3$, and $\mathrm{N} 2$ specimens can be eliminated by a postforming annealing treatment at $345^{\circ} \mathrm{C}$ for $1 \mathrm{~h}$.

From the electrochemical tests, the following results can be summarized: (1) both $\mathrm{S} 1$ and N1 possessed similar electrochemical behavior; (2) the superplastic forming process resulted in sensitization and formation of cavitation of the Al 5083 alloys that clearly influenced the electrochemical behavior; (3) postforming annealing treatment can recover the sensitization of the Al 5083 alloy; (4) the formation of cavitation led to the more active potentials of $E_{\text {corr }}, E_{b}$, and $E_{p p}$ and the higher current densities of $i_{\text {corr }}$ and $i_{p}$ measured in the $\mathrm{S} 2$ and $\mathrm{S} 4$ specimens.

Both the NAMLT test and electrochemical measurement can be employed to evaluate the susceptibility of the Al 5083 alloys after superplastic forming and various heat treatments. It appears that the solution of the NAMLT test was too aggressive to determine the effect of cavitation on the susceptibility of the superplastically formed specimen to intergranular corrosion. However, the electrochemical measurements in 3.5 wt. $\% \mathrm{NaCl}$ solution were more sensitive for clarifying the different effects between cavitation and sensitization.

\section{References}

1. R. Verma, A.K. Ghosh, S. Kim, and C. Kim: Mater. Sci. Eng., 1995, vol. 191A, pp. 143-50.

2. J. Wadsworth, T.G. Nieh, and O.B. Sherby: Superplasticity in Advanced Materials, Proc. JSRS Symp., S. Hori, M. Tokizane, and N. Furushiro, eds., Japan Society for Research on Superplasticity (JSRS), Tokyo, 1991, pp. 13-22.

3. R. Grimes and R.G. Butler: Superplasticity in Advanced Materials, Proc. JSRS Symp., S. Hori, M. Tokizane, and N. Furushiro, eds., Japan Society for Research on Superplasticity (JSRS), Tokyo, 1991, pp. 771-82.

4. Y.H. Tseng: Master's Thesis, National Taiwan University, Taipei, Taiwan, 1996

5. M.G. Vassilaros: in Life Predication of Corrodible Structure, R.N. Parkins, ed., NACE, Houston, TX, 1994, pp. 1656-67.

6. R.A. Corbett and B.J. Saldanha: Metals Handbook, 9th ed., vol. 13 , Corrosion, ASM International, Metals Park, OH, 1988, pp. 239-41.

7. R.B. Niederbweger, J.L. Basil, and G.T. Bedford: Corrosion, 1996, vol. 22, pp. 68-73.

8. R. Verma, P.A. Friedman, A.K. Ghosh, S. Kim, and C. Kim: J. Mater. Eng. Performance, 1995, vol. 4, pp. 543-50.

9. H. Iwasaki, T. Mori, T. Tagata, M. Matsuo, and K. Higashi: Mater Sci. Forum, 1997, vol. 233-234, pp. 81-88.

10. R. Verma, P.A. Friedman, A.K. Ghosh, S. Kim, and C. Kim: Metall. Mater. Trans. A, 1996, vol. 27A, pp. 1889-98.

11. T.C. Tsai, J.C. Chang, and T.H. Chuang: Metall. Mater. Trans. A, 1997, vol. 28A, pp. 2113-21.

12. M.S. Yeh: Ph.D. Thesis, National Taiwan University, Taipei, Taiwan, 1996, pp. 68-71.

13. D.J. Lloyd: Metall. Trans. A, 1980, vol. 11A, pp. 1287-94.

14. H. Iwasaki, K. Higashi, S. Tanimura, T. Komatubara, and S. Hayami: Superplasticity in Advanced Materials, Proc. JSRS Symp., S. Hori, M. Tokizane, and N. Furushiro, eds., Japan Society for Research on Superplasticity (JSRS), Tokyo, 1991, pp. 447-52.

15. H. Imamura and N. Ridley: Superplasticity in Advanced Materials, Proc. JSRS Symp., S. Hori, M. Tokizane, and N. Furushiro, eds., Japan Society for Research on Superplasticity (JSRS), Tokyo, 1991, pp. $453-58$

16. S.A. Saltkov: Stereometric Metallography, 2nd ed., Metallurgizdat, Moscow, 1958.

17. S. Maitra: Corrosion, 1981, vol. 37, pp. 125-31.

18. E.E. Underwood: Quantitative Stereology, Addison-Wesley, Reading, MA, 1970, pp. 30-33.

19. H. Kaesche: Localized Corrosion, NACE, Houston, TX, 1974, pp. 516-25.

20. H.L. Craig, Jr.: Localizes Corrosion-Cause of Metal Failure, ASTM STP 516, ASTM, Philadelphia, PA, 1972, pp. 17-37.

21. T.J. Summerson and D.O. Sprowls: Aluminum Alloys-Their Physical and Mechanical Properties, E.A. Starke and T.H. Sanders, Jr., eds., Engineering Materials Advisory Services Ltd., West Midlands, United Kingdom, 1986, pp. 1592-94.

22. E.H. Dix, Jr., W.A. Anderson, and M.B. Shumaker: Corrosion, 1959, vol. 15 , pp. 55t-61t

23. B. Mazurkiewicz: Corr. Sci., 1983, vol. 23, pp. 687-96.

24. C.C. Bampton, M.W. Mahoney, C.H. Hamilton, A.H. Ghosh, and R. Raj: Metall. Trans. A, 1983, vol. 14A, pp. 1583-91.

25. C.C. Bampton and R. Raj: Acta Metall., 1982, vol. 30, pp. 2043-53. 